\title{
Effects of fasting and refeeding on the metabolic functions of the turtle Kinosternon scorpioides (Linnaeus, 1766) raised in captivity ${ }^{1}$
}

\author{
Antonia S. Oliveira ${ }^{2 *}$, Cinthia G. Candioto ${ }^{3}$, Débora M.S. Santos ${ }^{4}$, José G. Pereira ${ }^{5}$, \\ Alana L. Sousa ${ }^{2}$ and Célio R. Machado ${ }^{6}$
}

\begin{abstract}
Oliveira A.S., Candioto C.G., Santos D.M.S., Pereira J.G., Sousa A.L. \& Machado C.R. 2013. Effects of fasting and refeeding on the metabolic functions of the turtle Kinosternon scorpioides (Linnaeus, 1766) raised in captivity. Pesquisa Veterinária Brasileira 33(8):1041-1044. Departamento das Clínicas do Curso de Medicina Veterinária, Universidade Estadual do Maranhão, Cidade Universitária Paulo VI, Tirirical, São Luís, MA 65050-150, Brazil. E-mail: antonia.santos3283@terra.com.br

The metabolic responses of adult and young freshwater Kinosternon scorpioides turtles raised in captivity were evaluated. Two experiments were performed: a) blood metabolite changes caused by food deprivation, and b) liver and muscle glycogen and total lipid differences after fasting and refeeding. Blood glucose concentration of young animals was susceptible to food deprivation. In both groups this metabolite decreased after 30 days of fasting. Feeding for 15 days did not recover blood glucose. Total seric proteins were not affected by food deprivation. Fasting decreased blood urea nitrogen and the highest difference was found around 30 days. Uric acid increased in young animals after 60 days of fasting. Triacylglicerol decreased after 15 days of fasting and refeeding for 15 days recovered the pre-fasting levels. Free fatty acid plasma tended to increase around 15 days of fasting. Liver glycogen decreased at day 15 of fasting, being stable thereafter while muscle glycogen decreased at a slower rate. Total liver lipid stabilized after 30 days and then decreased $70 \%$ after 60 days of fasting. Muscle lipids remained stable throughout fasting. It could be concluded that fasting of Kinosternon scorpioides led to metabolic adaptations similar to the one reported from reptiles and fish.
\end{abstract}

INDEX TERMS: Turtle, Kinosternon scorpioides, fasting, glucose, lipids, proteins.

RESUMO.- [Efeitos do jejum e da realimentação sobre as funções metabólicas da tartaruga Kinosternon scorpioides (Linnaeus, 1766) criada em cativeiro.] Neste tra-

\footnotetext{
${ }^{1}$ Received on March 29, 2013.

Accepted for publication on July 15, 2013.

${ }^{2}$ Departamento das Clinicas, Curso de Medicina Veterinária, Universidade Estadual do Maranhão (UEMA), Cidade Universitária Paulo VI, Caixa Postal 9, Tirirical, São Luís, MA 65050-150, Brazil. *Corresponding author: antonia.santos3283@terra.com.br

${ }^{3}$ Médica Veterinária autônoma. Private address: Rua Ipê 84, Jardim Hortência, Limeira SP 13485-051, Brazil.

${ }^{4}$ Departamento de Biologia, Curso de Biologia, UEMA, Cidade Universitária Paulo VI, Tirirical, São Luís, MA.

${ }^{5}$ Departamento de Patologia, Curso de Medicina de Veterinária, UEMA, Tirirical, São Luís, MA.

${ }^{6}$ Departamento de Morfologia e Fisiologia Animal, Faculdade de Ciências Agrárias e Veterinárias (FCAV), Universidade Estadual Paulista (Unesp), Via Paulo Donato Castellane, Jaboticabal, SP 14883-000, Brazil.
}

balho foi avaliada as respostas metabólicas da tartaruga Kinosternon scorpioides criada em cativeiro, nas fases, adultos e jovens nos estados: alimentado, jejuado e realimentado. $\mathrm{O}$ estudo compreendeu dois experimentos: (a) mudanças metabólicas no sangue causadas por privação alimentar e realimentação e (b) diferenças nas concentrações de glicogênio e lipídeos totais no fígado e no músculo após jejum e realimentação. No experimento dos animais jovens a concentração de glicose no sangue apresentou mudanças significativas. Entretanto, nos dois experimentos esse metabólito reduziu significativamente aos 30 dias de jejum. Realimentados por um período de 15 dias foi observado que a concentração de glicose não recuperou os níveis de pré-jejum. Concentração de glicose no sangue de animais jovens foi mais suscetível à privação de alimentos. Em ambos os grupos os metabólitos analisados decresceu após 30 dias de jejum. Retomando a alimentação por 15 dias foi 
observado que a concentração de glicose não recuperou. As concentrações de proteínas séricas totais não foram afetadas pela privação alimentar. 0 jejum decresceu a concentração de uréia no sangue e a maior diferença ocorreu aos 30 dias. 0 ácido úrico decresceu nos animais jovens após 60 dias de jejum. 0 triacilglicerol diminuiu após 15 dias de jejum e a realimentação por 15 dias recuperou os níveis de pré-jejum. 0 glicogênio hepático diminuiu aos 15 dias de jejum, e estabilizou a partir daí, enquanto o glicogênio muscular diminuiu a um ritmo mais lento. 0 lipídio total hepático total se manteve estável até os 30 dias de jejum, diminuindo até $70 \%$ aos 60 dias de jejum. E, em seguida, diminuiu $70 \%$ após 60 dias de jejum. Os lipídeos musculares permaneceram estáveis durante o jejum. Conclui-se que o jejum na espécie Kinosternon scorpioides apresentou adaptações metabólicas semelhantes aos relatados para outros répteis e peixes.

TERMOS DE INDEXAÇÃO: Tartaruga, Kinosternon scorpioides, jejum, glicose, proteínas, lipídeos.

\section{INTRODUCTION}

Understanding metabolic responses connected with feeding patterns is important for the health and welfare of captive reptiles. Studies of the freshwater turtle species Phrynops hilari and Chrysemys dorbigni have shown that fasting for 30 days did not alter the concentration of blood glucose (Machado 1977, Da Silva \& Migliorini 1990). However, glucose concentration of the sea turtle species Chelonia mydas and Lepidochelys kempi showed a drop of $29 \%$ and $22 \%$ after 7 and 21 days respectively (Moon et al. 1999).

Several reports demonstrated that vertebrates submitted to fasting show significant changes in the amount of body lipids and concentration of circulating fatty acids (Zammit \& Newsholme 1979, Groscolas 1986, Da Silva \& Migliorini 1990, Nordoy et al. 1993, Hervant et al. 2001, Freitas et al. 2003).

Studying the mobilization of liver and muscle glycogen in fasting, Da Silva \& Migliorini (1990) reported a significant reduction in the synthesis of liver and muscle glycogen in the turtle Phrynops hilari after a fasting period of 30 days.

The aim of this study was to evaluate the metabolic responses of the turtle Kinosternon scorpioides raised in captivity, subjected to feeding, to different intervals of fasting, and to refeeding. The concentrations of plasma glucose and urea, serum concentration of triglycerides, proteins, uric acid and fatty acids, and the concentrations of glycogen and total lipids of liver and muscle samples were determined. Knowledge of the metabolic responses such as revealed by this study is necessary for an understanding of basic biology, and for the improvement of nutrition to help conservation of this species in nature.

\section{MATERIALS AND METHODS}

We used 29 turtles (Kinosternon scorpioides) of both genders weighing on average between 135-460g. Animals were kept in boxes with a central water tank, at a room temperature of about $22^{\circ} \mathrm{C}$. Turtles were obtained from the scientific breeding facili-

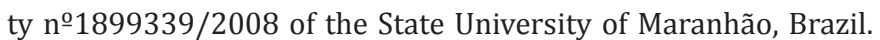
They were fed on alternate days at $5 \%$ body weight with commercial feed pellets (Acqua Fri-28) containing 28.83\% crude protein, $36.03 \%$ raw fiber, and $5.05 \%$ ether extract, as described elsewhere (Luz 2004). Animals were submitted to this regimen for 60 days to adapt to the feeding patterns designed by this study before samples were drawn from the animals, as described later in this section. Samples were drawn from the animals over the following 75 days, with the experimental protocol thus lasting for 135 days in all.

The study protocol was approved by the Ethical Committee and Animal Welfare of the State University Paulista Julio de Mesquita Filho-Unesp/Jaboticabal, protocol no 012217. The study was also approved by Brazilian Institute of Environment and Renewable Natural Resources (IBAMA-MA).

The turtles were divided into two different experimental study designs. For the experimental design I, we split 24 animals into two groups (Adult animals and Young animals). The Adult group comprised 12 adult animals over 5 years of age and of average weight of $375.83 \pm 24.94 \mathrm{~g}$, while the Young group comprised 12 animals with two years of age and of average weight of $199.58 \pm 41.04 \mathrm{~g}$. These groups were subjected to biochemical analyses such as glucose and protein in plasma and urea, uric acid, triglycerides, and free fatty acid in serum of blood as described in the following sections.

Experimental design II consisted of 5 turtles with 5 years of age and weighing $442 \pm 17.54 \mathrm{~g}$. In these animals the percentages of glycogen and total lipids gathered from muscle (pectoralis major) and liver samples were obtained by necropsy as described in the following sections. The small number of animals in experiment 2 was due to limitations imposed by the Brazilian Institute of Environment and Renewable Natural Resources (IBAMA-MA) in order to authorize the study.

Samples of $1 \mathrm{~mL}$ of blood were collected from the dorsal cervical sinus. The blood was then rapidly added to test tubes containing $0.5 \mathrm{~mL}$ sodium fluoride. Plasma and serum samples were frozen for subsequent biochemical analysis.

Free fatty acids were measured using commercial kits (Wako Chemicals NEFA HR (2), 0108 DI 434-91795, Germany) and modified spectrophotometry at 560nm (Dynex Tecnnologies MRXTC Plus, USA). Seric uric acid, triacylglycerol, glucose, urea, and total protein were determined by using commercial kits obtained from Labtest Sistemas de Diagnósticos Ltda (Belo Horizonte, Brazil) according to the manufacturer's instructions.

Total lipid content of liver and muscle was determined by gravimetry after extraction with chloroform-methanol (2:1 v/v), as described by Bligh \& Dyer (1959). Liver and muscle glycogen was measured according to Moon et al. (1989).

The experimental design I was completely randomized and factorial $(2 \times 5)$, consisting of two groups and five feeding states (fed, fasted for 15, 30, and 60 days and refed). Results were obtained by variance analysis (ANOVA) and the obtained means compared by the Tukey test (5\%) by using the program Statistical Analysis System (SAS 2005).

Experimental design II young animals were euthanized with intravenous injection of $2 \%$ xylazine and 1\% ketamine hydrochloride using a lethal dose of 2 and $60 \mathrm{mg} / 100 \mathrm{~g}$ of body weight respectively. We proceeded with necropsy by dismantling of the bone bridge, separating the carapace and plastron with the aid of surgical instruments and removal of organs and tissues.

Fragments of the liver's left lobe and pectoralis major muscles were collected during the procedure. Excess blood from the samples was absorbed with paper towel and the fragments were wrapped in foil, maintained on crushed ice, and subsequently frozen at $-20^{\circ} \mathrm{C}$. 


\section{RESULTS}

To investigate the relationship between the Adult and Young groups of turtles and the feeding states, we performed analysis of variance and the comparisons of the variables mean plasma glucose, protein, urea, triglyceride, and free fatty acid concentrations obtained from the Adult and Young groups in fed, fasted, and refed states (Table 1). The $\mathrm{F}$ test showed no interaction between the groups and the feeding states studied.

However, significant interactions were observed by Tukey tests after 30 days of fasting, when a significant decrease in blood glucose concentration was observed. This reduction continued even when the animals were fed again. Triacylglycerols and urea significantly reduced throughout the period of food restriction. The concentration of proteins and free fatty acids remained constant throughout the period of food restriction compared to the fed and refed state periods.
Analysis of variance by $\mathrm{F}$ test showed that the variables Group and Feeding state led to significant effects on the concentration of uric acid of Young animals at the 60th day of fasting (Table 2). Interaction analysis (Tukey test) showed that the two groups (Adult and Young) presented similar profiles for all the biochemical parameters analyzed except for the Young group fasted for 60 days. In this case these turtles significantly increased the seric uric acid levels compared to Adult animals (Table 2).

Fasting induced a progressive decrease in the concentrations of liver and muscle glycogen as shown in Figure 1. Compared to the fed state, turtles subjected to 15 days of fasting showed decreased hepatic glycogen concentration by about $56 \%$, then a further reduction by $25 \%$ at 30 days of fasting which was kept constant up to the 60th day of food restriction. Liver lipid reserves suffered a significant decrease only at 60 days of fasting while no changes were observed in muscle tissue (Fig.2).

Table 1. Biochemical parameters of Young and Adult groups of the species Kinosternon scorpioides, subjected to feeding, fasting, and refeeding. Jaboticabal/SP, 2010

\begin{tabular}{lccccc}
\hline \multicolumn{1}{c}{ Statistics } & \multicolumn{5}{c}{ Variables } \\
\cline { 2 - 6 } & $\begin{array}{c}\text { Glucose } \\
(\mathrm{mg} / \mathrm{dL})\end{array}$ & $\begin{array}{c}\text { Protein } \\
(\mathrm{g} / \mathrm{dL})\end{array}$ & $\begin{array}{c}\text { Urea } \\
(\mathrm{mg} / \mathrm{dL})\end{array}$ & $\begin{array}{c}\text { Triacylglycerol l } \\
(\mathrm{mg} / \mathrm{dL})\end{array}$ & $\begin{array}{c}\text { FFA } \\
(\mu \mathrm{mol} / \mathrm{dL})\end{array}$ \\
\hline F for Young and Adult groups $(\mathrm{G})$ & $3.84^{* *}$ & $1.00 \mathrm{~ns}$ & $3.03^{* *}$ & $2.21^{*}$ & $0.81 \mathrm{~ns}$ \\
F for Feeding states (S) & $11.00^{* *}$ & $2.50^{*}$ & $14.22^{* *}$ & $14.43^{* *}$ & $0.79 \mathrm{~ns}$ \\
F in GxS & $0.76 \mathrm{~ns}$ & $1.32 \mathrm{~ns}$ & $1.47 \mathrm{~ns}$ & $2.25 \mathrm{~ns}$ & $0.75 \mathrm{~ns}$ \\
VC $(\%)$ & 24.26 & 22.01 & 45.67 & 56.69 & 48.77 \\
Mean Adult group & $50.84 \pm 21.32 \mathrm{~B}$ & $5.65 \pm 1.15$ & $29.88 \pm 19.23 \mathrm{~A}$ & $274.69 \pm 175.66 \mathrm{~A}$ & $0.57 \pm 0.26$ \\
Mean Young group & $61.29 \pm 19.92 \mathrm{~A}$ & $5.74 \pm 1.43$ & $21.26 \pm 11.61 \mathrm{~B}$ & $217.40 \pm 198.95 \mathrm{~B}$ & $0.53 \pm 0.26$ \\
Mean fed & $65.19 \pm 16.00 \mathrm{a}$ & $5.80 \pm 0.57$ & $31.45 \pm 16.49 \mathrm{ab}$ & $390.07 \pm 210.48 \mathrm{a}$ & $0.51 \pm 0.24$ \\
Mean fasted 15 d & $63.84 \pm 18.97 \mathrm{a}$ & $6.02 \pm 1.02$ & $21.33 \pm 11.13 \mathrm{c}$ & $134.39 \pm 105.02 \mathrm{~b}$ & $0.63 \pm 0.31$ \\
Mean fasted 30 d & $58.23 \pm 18.98 \mathrm{ab}$ & $5.07 \pm 0.79$ & $15.04 \pm 7.49 \mathrm{c}$ & $168.94 \pm 167.07 \mathrm{~b}$ & $0.55 \pm 0.27$ \\
Mean fasted 60 d & $50.47 \pm 19.02 \mathrm{bc}$ & $6.03 \pm 2.09$ & $22.51 \pm 15.83 \mathrm{bc}$ & $174.29 \pm 113.21 \mathrm{~b}$ & $0.58 \pm 0.26$ \\
Mean refed & $40.90 \pm 14.33 \mathrm{c}$ & $5.54 \pm 1.20$ & $39.17 \pm 18.74 \mathrm{a}$ & $341.17 \pm 176.37 \mathrm{a}$ & $0.49 \pm 0.20$
\end{tabular}

Means followed by the same letter (uppercase for groups and lowercase for feeding states) did not differ by Tukey test $\alpha=5 \%$. ${ }^{* *} \mathrm{P}<0.01,{ }^{*} \mathrm{P}<0.05$, ns Not significant $(\mathrm{P} \geq 0.05), d=$ days, FFA, free fatty acids, $\mathrm{VC}=$ variation coefficient.

Table 2. Seric uric acid (mg/dL) groups of Young and Adult animals of the species Kinosternon scorpioides, subjected to feeding, fasting, and refeeding. Jaboticabal/SP, 2010

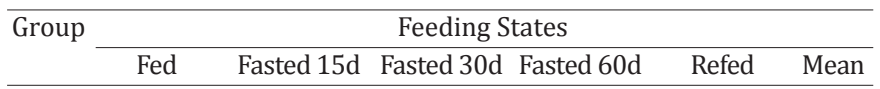

Adult $0.63 \pm 0.11 \mathrm{~B} \quad 1.41 \pm 0.74 \mathrm{~B} \quad 0.74 \pm 0.23 \mathrm{~B} \quad 0.97 \pm 0.59 \mathrm{~B} \quad 0.84 \pm 0.21 \mathrm{~B} \quad 0.99 \mathrm{~B}$

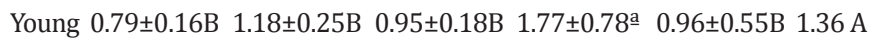

Means followed by the same letter (uppercase in the same column) for the groups did not differ by Tukey $\alpha=5 \%$. $D=$ days.

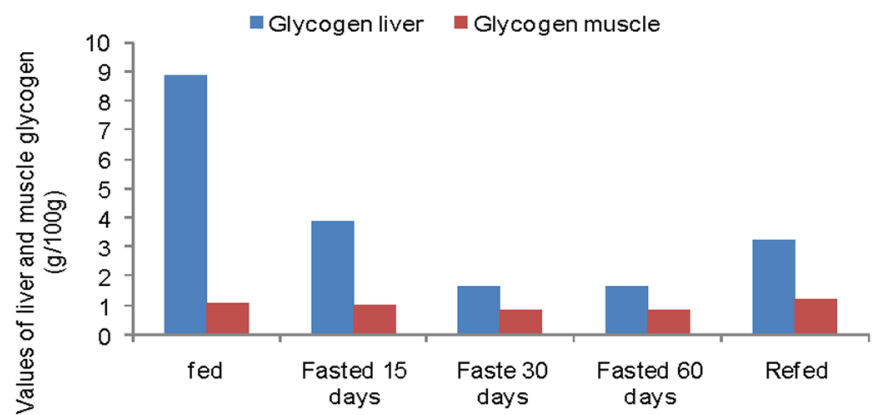

Fig.1. Values of liver and muscle glycogen (g/100g) measured from animals subjected to feeding, fasting and refeeding. Jaboticabal/SP, 2010.

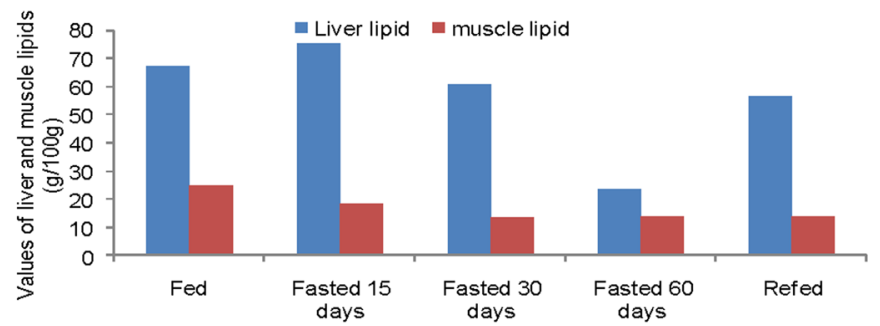

Fig.2. Concentration of liver and muscular (g/100g) lipids measured from animals subjected to feeding, fasting and refeeding. Jaboticabal/SP, 2010.

\section{DISCUSSION}

Because food restriction reduced blood glucose concentration after 30 days of fasting it is reasonable to conclude that at this point the turtles had used their entire stock of glucose. Indeed there was a reduction of glycogen after 15 days of fasting, suggesting that glucose concentration at the 15 th day of fasting was maintained by hepatic gluconeogenesis, a finding which is in accordance to a previous study.

The glycemic responses found in this study with the turtle Kinosternon scorpioides are similar to those found in Chelonia mydas (Bonnet 1979, Moon et al. 1999), in Rha- 
mdia hilarii, (Machado et al. 1988) and in Lepidochelys kempi (Moon et al. 1999). Glycogen concentration results found in this study are in agreement with those found by Da Silva \& Migliorini (1990), who observed a significant reduction in the synthesis of liver and muscle glycogen in the turtle Phrynops hilarii fasted for 30 days.

Our study shows that plasma protein concentration was not modified during periods of food restriction, indicating that the turtles retained their essential biological processes through hepatic glycogen and lipid reserves. These results are similar to those found by Moon et al. (1999) in Chelonia mydas and Lepidochelys kempi and by Bonnet (1979) in Chelonia mydas.

The observed urea decrease found in turtles under food restriction suggests that there was no protein mobilization. In contrast, decrease in uric acid concentration at 60 days of food restriction in young animals suggests that young reptiles are less tolerant to hypoglycemia than adults, and therefore activate protein mobilization.

The significant reduction observed in the concentration of triacylglycerols is in agreement with the mobilization of liver lipids. However, as an increase in fatty acids was not observed, it is possible that at the same time as lipid mobilization, breakdown of triacylglycerols and fatty acid oxidation for energy production was taking place. This suggestion is consistent with the observation that at 15 days of fasting fatty acid levels were frequently increased, although no statistical difference was found between these results and those of and the refed group, in which the liver glycogen was almost depleted.

\section{CONCLUSIONS}

We conclude that fasting of the turtle Kinosternon scorpioides led to similar metabolic adaptations previously reported for other reptiles and fish.

Our results revealed that liver glycogen is the first reserve to be mobilized, followed by lipolysis and a slow metabolic response pattern.

The findings of this study will contribute to further understanding of metabolic responses connected with feeding patterns, and to the improvement of nutritional programs important for health and welfare of captive reptiles.
Acknowledgements.- The authors acknowledge the Inter-institutional Doctoral Program (DINTER) Convention CAPES (Coordination for the Improvement of Higher Education), State University Paulista Julio de Mesquita Filho-Unesp/Jaboticabal and State University of Maranhão (UEMA) for the technical and financial support of the research.

\section{REFERENCES}

Bligh E.G. \& Dyer W.J. 1959. A rapid method of total lipid extraction and purification. Can. J. Biochem. Physiol. 37(8):911-917.

Bonnet B. 1979. Influence of the nutritional conditions on the organic composition of blood and urine in the juvenile sea turtle Chelonia mydas L. Aquaculture 16(3):253-260.

Da Silva R.S.M. \& Migliorini R.H. 1990. Effects of starvation and refeeding on energy-linked metabolic processes in the turtle (Phrynops hilarii). Comp. Biochem. Physiol. A, Physiol. 96(3):415-419.

Freitas M.B., Welker A.F., Millan S.F. \& Pinheiro E.C. 2003. Metabolic responses induced by fasting in the common vampire bat Desmodus rotundus. J. Comp. Physiol. B 173(8):703-707.

Groscolas R. 1986. Changes in body mass, body temperature and plasma fuel levels during the natural breeding fast in male and female emperor penguins Aptenodytes forsteri. J. Comp. Physiol. B 156:521-527.

Hervant F., Meathieu J. \& Durand J. 2001. Behavioural, physiological and metabolic responses to long-term starvation and refeeding in a blind cave-dwelling (Proteus anguinus) and a surface-dwelling (Euproctus asper) salamander. J. Exp. Biol. 204(Pt 2):269-281.

Luz V.L.F. 2004. Criação e conservação de quelônios e outros répteis: biologia e conservação de quelônios de água doce e criação de quelônios. Instituto Brasileiro do Meio Ambiente e dos Recursos Renováveis (IBAMA), Goiânia, GO.

Machado S.C. 1977. Mobilização dos ácidos graxos livres em Chrysemys dorbigni (Reptidia, Chelonia). Dissertação de Mestrado, Universidade Federal do Rio Grande do Sul, Porto Alegre, RS.

Moon T.W., Foster G.D. \& Plisetskaya E.M. 1989. Changes in peptide hormones and liver enzymes in the rainbow trout deprived of food 6 weeks. Can. J. Zool. 67(9):2189-2193.

Moon D.Y., Owens D.W. \& Mackenzie D.S. 1999. The effects of fasting and increased feeding on plasma thyroid hormones, glucose, and total protein in sea turtles. Zoolog. Sci. 16(4):579-586.

Nordoy E.S., Aakvaag A. \& Larsen T.S. 1993. Metabolic adaptations to fasting in harp seal pups. Physiol. Zool. 66(6):926-945.

SAS 2005. SAS User's Guide. Versão 9.1. Statistics Analysis System. SAS Institute, Cary, NC, USA.

Zammit V.A. \& Newsholme E.A. 1979. Activities of enzymes of fat and ketone-body metabolism and effects of starvation on blood concentrations of glucose and fat fuels in teleost and elasmobranch fish. Biochem. J. 184(2):313-322. 